Duty to State Reasons and Competition Investigation

pÿInformation Request Decisions: the Cement Judgments in Cases C-247/14 P, C-248/14 P, C-267/14 P and C-268/14 P

\author{
Havu, Katri Annikki
}

2016

Havu , K A 2016 , ' Duty to State Reasons and Competition Investigation Information pÿRequest Decisions: the Cement Judgments in Cases C-247/14 P, C-248/14 P, C-267/14

P and C-268/14 P' , Review of European Administrative Law , vol. 9 , no. 2 , pp. 43-59 . https://doi.org/10.7590/1874

http://hdl.handle.net/10138/315222

https://doi.org/10.7590/187479816X14804950850195

unspecified

publishedVersion

Downloaded from Helda, University of Helsinki institutional repository.

This is an electronic reprint of the original article.

This reprint may differ from the original in pagination and typographic detail.

Please cite the original version. 


\title{
Duty to State Reasons and Competition Investigation Information Request Decisions: the 'Cement Judgments' in Cases C-247/14 P, C-248/14 P, $\mathrm{C}-267 / 14 \mathrm{P}$ and C-268/14 P
}

Katri Havu*

Doctor of Laws and Postdoctoral Researcher, University of Helsinki

\begin{abstract}
The Court of Justice of the EU has set aside a group of General Court judgments and annulled a set of information request decisions by the European Commission. The requests for information, adopted in the form of decisions in the context of a competition infringement investigation, were comprehensive but accompanied by notably vague and concise statements of reasons. The Court of Justice of the EU has found that the General Court erred in law when finding the information request decisions adequately reasoned. The judgments entail important clarifications of the duty to state reasons in the specific context of competition investigations.
\end{abstract}

\section{Introduction}

Article 296 TFEU and case law interpreting that provision require that measures adopted by EU institutions must be appropriate to the measure at issue and must disclose clearly and unequivocally the reasoning followed by the institution which adopted the measure. It must be possible for the persons concerned to ascertain the reasons for the measure and to enable a competent court to review its legality. The requirements to be satisfied by a statement of reasons depend on the circumstances of each case. Whether a statement of reasons meets the requirements of Article 296 TFEU must be assessed with regard not only to the wording of the statement but also to its context and to the legal rules governing the matter in question. ${ }^{2}$

* DOI $10.7590 / 187479816 X_{14} 804950850195$

1 See, e.g., Case C-455/11 P Solvay v. Commission EU:C:2013:796, para. 90; Case C-367/95 P Commission v. Sytraval and Brink's France EU:C:1998:154, para. 63.

2 See, e.g., Case C-37/13 P Nexans and Nexans v. Commission EU:C:2014:2030, paras. 31-33; Case C-455/11 P Solvay v. Commission EU:C:2013:796, para. 91. See also, e.g., A. Simonati, 'The Principles of Administrative Procedure and the EU Courts: an Evolution in Progress?', REALaw [2011], 45-82, 51-54, 77. 
Under Article 18 of Regulation 1/2003, , the European Commission ('Commission'), in order to carry out its duties in terms of investigating and finding infringements of Articles 101 and 102 TFEU, may, either by a simple request or by a decision, 'require undertakings and associations of undertakings to provide all necessary information' (Art. 18(1)). According to Article 18(3), when requesting information by a decision, the Commission should 'state the legal basis and the purpose of the request, specify what information is required' and set a time limit for providing the information. ${ }^{4}$ Additionally, the Commission must indicate penalties - potentially significant fines or periodic penalty payments - relevant in the case of failure to react to an information request decision. Furthermore, the Commission must indicate the right to have the decision reviewed by the EU Courts.

The possibility to issue information requests is essential for the Commission to be able to investigate suspected competition law infringements. A comprehensive fact-finding phase may precede the formal opening of proceedings against an undertaking. Discovering concealed illicit practices that are detrimental to society is both challenging and important. Information requests and other powerful tools for gathering information, such as inspections (also known as 'dawn raids'), should nevertheless be used wisely, balancing different interests. Complying with information requests or undergoing inspections may be significantly time and resource consuming for the undertakings involved (and thus, furthermore, negatively affect overall welfare). Moreover, fact-finding exercises should not infringe general principles of EU law or fundamental rights. ${ }^{5}$ As the cases discussed in this article also illustrate, the Commission must not undertake comprehensive 'fishing expeditions' or issue almost random information requests, especially later in an investigation.

Article 296 TFEU with the case law interpreting the provision and the specific requirements of Article 18 of Regulation 1/2003 together form the relevant EU law as regards the appropriateness of the statement of reasons in an infor-

3 Council Regulation No. $1 / 2003$ of 16 December 2002 on the implementation of the rules on competition laid down in Articles 81 and 82 of the Treaty [2003] OJ L 1/1.

4 Recital 23 of Regulation 1/2003 states that the Commission should be empowered to require 'such information to be supplied as is necessary to detect' an infringement of competition rules. The Recital clarifies that undertakings cannot be forced to admit that they have committed an infringement, but they are obliged to answer factual questions and to provide documents.

5 See further, e.g., M. Kellerbauer/R. Sauer/C. Hödlmayr/L. Ortiz Blanco/K. Jörgens, 'Investigation of Cases (II): Formal Investigative Measures in General, Requests for Information, and Interviews', in L. Ortiz Blanco (ed.), EU Competition Procedure (Oxford: OUP, 3rd edn., 2013), 277-313, 277-282, 290-309; C.S. Kerse/N. Khan, EC Antitrust Procedure (London: Sweet \& Maxwell, 5th edn., 2005), 38-40, 125-143; M. Prek/S. Lefevre, 'Competition Litigation before the General Court: Quality If Not Quantity?’, CMLR [2016], 65-90, 82-89; P. Craig, EU Administrative Law (Oxford: OUP, 2nd edn., 2012), 348. 
mation request decision. The adequacy of such statements of reasons lies at the core of four judgments by the Court of Justice of the EU ('CJEU') issued on 10 March 2016, the 'Cement Judgments'. The CJEU set aside a group of General Court ('GC') judgments, which had found the statements of reasons adequate, and annulled the corresponding Commission information request decisions. The four CJEU judgments are essentially alike. ${ }^{6}$

The Cement Judgments underline that the earlier steps in an investigation affect the requirements as regards indicating the purpose of an information request and suspected infringements. Potential infringements may not be referred to in an excessively vague manner if, from an objective perspective, the Commission could present more detailed descriptions.

As regards competition infringement investigations and procedures relevant in the Cement case, the case was closed without finding an infringement in 2015. Nevertheless, some of the appeals concerning the lawfulness of the Commission's information requests remained pending, resulting in the four judgments by the CJEU.

\section{$2 \quad$ Facts and Background}

The competition investigations which form the background to the Cement Judgments concerned several cement companies in the EU area. In November 2008 and September 2009, the Commission carried out inspections at the premises of many undertakings and, on 6 December 2010, initiated formal proceedings for alleged competition infringements against several cement companies. The Commission described the suspected infringements in highly general terms. ${ }^{7}$ On 30 March 2011, when the Commission issued information requests, in the form of decisions, requiring the undertakings concerned to answer a questionnaire that related to suspected infringements, the suspicions were still written out vaguely. ${ }^{8}$

6 See Cases C-247/14 P HeidelbergCement v. Commission EU:C:2016:149; C-248/14 P Schwenk Zement v. Commission EU:C:2016:150; C-267/14 P Buzzi Unicem v. Commission EU:C:2016:151; C-268/14 P Italmobiliare v. Commission EU:C:2016:152.

7 See further Cases C-247/14 P HeidelbergCement AG v. Commission EU:C:2016:149, para. 4; C-248/14 P Schwenk Zement v. Commission EU:C:2016:150, para. 4; C-267/14 P Buzzi Unicem v. Commission EU:C:2016:151, para. 4; C-268/14 P Italmobiliare v. Commission EU:C:2016:152, para. 4. See also CJEU Press Release $27 / 16$ 'The Court of Justice annuls the Commission decisions relating to requests for information directed at cement manufacturers', Luxembourg (10 March 2016).

8 Commission Decisions C (2011) 2356 final, C (2011) 2361 final, C (2011) 2364 final and C (2011) ${ }_{23} 67$ final of 30 March 2011 relating to a proceeding under Article 18(3) of Council Regulation (EC) No. 1/2003, Case COMP/39520 - Cement and related products. 
Among several companies, HeidelbergCement AG ('HeidelbergCement'), Schwenk Zement KG, Buzzi Unicem SpA, and Italmobiliare SpA ('the Appellants'), brought actions for annulment before the GC. They argued, among other issues, that the Commission had failed to adequately describe the alleged competition infringements and that the information requests were disproportionately burdensome. The GC essentially dismissed the actions, noting that the information request decisions had been lawful. ${ }^{9}$ The GC found only a minor issue regarding which the claims of one Appellant should be upheld. ${ }^{10}$

The Appellants brought the case to the CJEU in order to set aside the GC judgments and annul the Commission information request decisions. In their appeals, they argued, in particular, that the GC had erred in law when it found the statements of reasons by the Commission to be adequate, and, for example, that the GC had erroneously evaluated the necessity for the information requested, that the GC erred in law when it considered that the Commission was entitled to request information in a specific format, and that the GC wrongly interpreted the right not to incriminate oneself. ${ }^{11}$

\section{Reasoning of the Court}

The CJEU started its analysis by evaluating the grounds of appeal relating to the GC's error of law when it reviewed compliance with the requirements for Commission decisions under Article 18(3) of Regulation 1/2003 and the duty to state reasons. In particular, this issue was about indicating the aim of the information requests. ${ }^{12}$ The GC had found the Appellants' arguments alleging failure to state sufficient reasons unfounded. ${ }^{13}$ The Appellants argued,

9 See Cases T-302/11 HeidelbergCement v. Commission EU:T:2014:128; T-306/11 Schwenk Zement v. Commission EU:T:2014:123; T-297/11 Buzzi Unicem v. Commission EU:T:2014:122; T-305/11 Italmobiliare v. Commission EU:T:2014:126.

10 The GC found, regarding Schwenk Zement KG, that the time limit for answering certain questions was disproportionate and insufficient. See Case T-306/11 Schwenk Zement v. Commission EU:T:2014:123.

11 See further Opinion by Advocate General ('AG') Wahl in Case C-247/14 P HeidelbergCement v. Commission EU:C:2015:694; Opinion by AG Wahl in Case C-248/14 P Schwenk Zement v. Commission EU:C:2015:695; Opinion by AG Wahl in Case C-267/14 P Buzzi Unicem v. Commission EU:C:2015:696; Opinion by AG Wahl in Case C-268/14 P Italmobiliare v. Commission $\mathrm{EU}: \mathrm{C}: 2015: 697$.

12 See, e.g., Case C-247/14 P HeidelbergCement v. Commission EU:C:2016:149, para. 11. See also paras. 10, 12-15. See further, e.g., Case C-248/14 P Schwenk Zement v. Commission EU:C:2016:150, paras. 11-16.

13 See note 9 supra. 
furthermore, that even the GC's judgments on this issue were insufficiently reasoned. ${ }^{14}$

The Commission emphasised that the requirement to state reasons must be adapted to the circumstances of the case and that information requests are investigative measures generally used in the preliminary fact-finding stage. The fact that the Commission at that stage does not have detailed information at its disposal should signify that it is not necessary to describe in detail the nature, geographical scope and duration of the suspected infringement, or the products concerned by it, in order to comply with Article 18(3) of Regulation 1/2003 and EU law. Furthermore, the Commission highlighted that information request decisions and decisions to initiate formal proceedings contained specific information on the alleged infringement and participants in it. Hence, the information request decisions, read in conjunction with the decisions to initiate proceedings, included sufficient guidance as regards the purpose of the request for information, and the GC correctly, and without infringing its own obligation to state reasons, found the requests for information lawful. ${ }^{15}$

The CJEU noted, as a starting point, that the issue whether the GC had erred in law in dismissing the plea concerning inadequate statement of reasons was a question of law and subject to review by the CJEU on appeal. ${ }^{16}$ The CJEU continued by recalling settled case law on the duty to state reasons under Article 296 TFEU, highlighting that it is not necessary that the reasoning includes all the relevant facts and points of law because the issue whether a statement of reasons complies with Article 296 TFEU must be assessed taking into account, in addition to its wording, the context and all the legal rules governing the matter in question. ${ }^{17}$

Additionally, the CJEU noted that Article 18(3) of Regulation 1/2003 defines the essential elements of a statement of reasons for an information request decision. ${ }^{18}$ It underlined that the obligation to state specific reasons set out in

14 See, e.g., Case C-247/14 P HeidelbergCement v. Commission EU:C:2016:149, para. 12. See also Opinion by AG Wahl in Case C-248/14 P Schwenk Zement v. Commission EU:C:2015:695, paras. 41-44.

15 See Cases C-247/14 P HeidelbergCement v. Commission EU:C:2016:149, paras. 13-14; C-248/14 P Schwenk Zement v. Commission EU:C:2016:150, paras. 13-15; C-267/14 P Buzzi Unicem v. Commission EU:C:2016:151, paras. 14-15; C-268/14 P Italmobiliare v. Commission EU:C:2016:152, paras. 15-16.

16 See, e.g., Case C-247/14 P HeidelbergCement v. Commission EU:C:2016:149, para. 15 .

17 See, e.g., ibid., para. 16; Case C-248/14 P Schwenk Zement v. Commission EU:C:2016:150, para. 20. See also Case C-37/13 P Nexans and Nexans v. Commission EU:C:2014:2030, paras. 31-33; Case C-367/95 P Commission v. Sytraval and Brink's France EU:C:1998:154, para. 63.

18 See, e.g., Case C-247/14 P HeidelbergCement v. Commission EU:C:2016:149, paras. 17-18; Case C-248/14 P Schwenk Zement v. Commission EU:C:2016:150, paras. 21-22. 
the provision is a fundamental requirement the purpose of which is not only to show that the request is justified but also to enable the undertakings concerned to evaluate the scope of their duty to cooperate and to safeguard companies' rights of defence. The CJEU referred here to case law on another type of information gathering decisions, that is, inspection decisions, noting that cases were relevant by analogy. ${ }^{19}$

Regarding the obligation to state the 'purpose of the request' (Art. 18(3) of Regulation 1/2003), the CJEU explained that this relates to the obligation to indicate the subject of the Commission's investigation and thus to the duty to identify the alleged competition infringement. ${ }^{20}$ It is not required that the Commission communicates to the addressees of an information request decision all the information at its disposal concerning suspected infringements, or conducts a precise legal analysis of those infringements, provided that it 'clearly indicates the suspicions which it intends to investigate'. ${ }^{21}$

The CJEU noted that this obligation may be explained, among other issues, by the fact that Article 18(1) and Recital 23 of Regulation 1/2003 allow the Commission to require submission of 'all necessary information'- which signifies that the Commission may require disclosure only of information which may enable it to investigate presumed infringements. According to the CJEU, the GC had correctly noted this issue, for instance, concerning the action by HeidelbergCement. $^{22}$

The CJEU underlined that because the necessity for information must be assessed in relation to the purpose stated in the request, that purpose must be indicated with sufficient precision. Failure to do so would both make it impossible to determine whether the information is necessary and prevent the exercise of any judicial review. ${ }^{23}$ Thus - as the GC had for instance also held in

19 See, e.g., Case C-247/14 P HeidelbergCement v. Commission EU:C:2016:149, para. 19; Case C-248/14 P Schwenk Zement v. Commission EU:C:2016:150, para. 23. The cases cited were Joined Cases 97/87 to 99/87 Dow Chemical EU:C:1989:380; Case C-94/00 Roquette Frères EU:C:2002:603; Case C-583/13 P Deutsche Bahn and Others v. Commission EU:C:2015:404; Case C-37/13 P Nexans and Nexans v. Commission EU:C:2014:2030.

20 See e.g., Case C-247/14 P HeidelbergCement v. Commission EU:C:2016:149, para. 20. See also Case C-36/92 P SEP NVv. Commission EU:C:1994:205, para 21; Opinion by AG Jacobs in Case C-36/92 P SEP NVv. Commission EU:C:1993:928, paras. 22-34.

21 See e.g., Case C-247/14 P HeidelbergCement v. Commission EU:C:2016:149, para. 21. Case C-37/13 P Nexans and Nexans v. Commission EU:C:2014:2030, para. 35 and case law cited there was again referred to as being relevant by analogy.

22 See e.g., Case C-247/14 P HeidelbergCement v. Commission EU:C:2016:149, paras. 22-23. See also, e.g., Case T-302/11 HeidelbergCement v. Commission EU:T:2014:128, para. 34 .

23 See, e.g., Case C-247/14 P HeidelbergCement v. Commission EU:C:2016:149, para. 24; Case C-248/14 P Schwenk Zement v. Commission EU:C:2016:150, para. 28. See also Case C-36/92 P SEP NV v. Commission EU:C:1994:205, para 21; Opinion by AG Jacobs in Case C-36/92 P SEP NV v. Commission EU:C:1993:928, in particular, para. 34 . 
the case of HeidelbergCement's action - the adequacy of the statements of reasons here depended on whether the infringements that the Commission intended to investigate were defined sufficiently clearly. ${ }^{24}$

Proceeding to evaluate whether the GC had erred in law when it found that the statements of reasons of the Commission decisions were adequate, the CJEU noted that the GC had remarked that the statements of reasons were formulated in very general terms but that the 'reference to restrictions on imports in the European Economic Area (EEA), to market-sharing and to price coordination in the cement market and related product markets, read in conjunction with the decision to initiate proceedings' had the minimum degree of clarity necessary to find that the requirements of Article 18(3) of Regulation $1 / 2003$ had been met. $^{25}$

The CJEU highlighted that the Commission had asked the Appellants to answer a questionnaire annexed to each decision. The matters referred to in the annex were notably numerous and covered different types of information. In particular, the questionnaire required disclosure of extensive and detailed information relating to a significant number of both domestic and international transactions, in relation to twelve Member States over a period of ten years. ${ }^{26}$ Nevertheless, the decisions did not clearly and unequivocally disclose suspicions of infringement and did not enable a determination whether the information requested was necessary for the investigation. The information request decisions only contained excessively brief statements of reasons which were vague, especially when observed in the light of the length of the annexed questionnaire and the fact that the requests were presented in a situation where submission of information had already taken place throughout the investigation. ${ }^{27}$

24 See e.g., Case C-247/14 P HeidelbergCement v. Commission EU:C:2016:149, para. 25; Case T-302/11 HeidelbergCement v. Commission EU:T:2014:128, para. 39.

25 See Case C-247/14 P HeidelbergCement v. Commission EU:C:2016:149, para. 26; Case T-302/11 HeidelbergCement v. Commission EU:T:2014:128, paras. 42-43. See also similarly, e.g., Case C-248/14 P Schwenk Zement v. Commission EU:C:2016:150, para. 30; Case T-306/11 Schwenk Zement v. Commission EU:T:2014:123, paras. 37-38.

26 See Case C-247/14 P HeidelbergCement v. Commission EU:C:2016:149, para. 27. See also similarly Case C-248/14 P Schwenk Zement v. Commission EU:C:2016:150, paras. 31-32; Case C-267/14 P Buzzi Unicem v. Commission EU:C: 2016:151, paras. 28-29; Case C-268/14 P Italmobiliare v. Commission EU:C:2016:152, paras. 29-30. See further Commission Decisions C (2011) 2356 final, C (2011) 2361 final, C (2011) 2364 final and C (2011) 2367 final of 30 March 2011 relating to a proceeding under Article 18(3) of Council Regulation (EC) No. 1/2003, Case COMP/39520 Cement and related products.

27 See, e.g., Case C-247/14 P HeidelbergCement v. Commission EU:C:2016:149, paras. 27-31; Case C-248/14 P Schwenk Zement v. Commission EU:C:2016:150, paras. 31-34; Commission Decisions $\mathrm{C}$ (2011) 2361 final and C (2011) 2367 final of 30 March 2011 relating to a proceeding under Article 18 (3) of Council Regulation (EC) No. 1/2003, Case COMP/39520 - Cement and related products. The information request decisions themselves noted the fact that information had already been submitted earlier. 
For example, in the decision addressed to HeidelbergCement, the two Recitals that contained the statement of reasons read:

' 1 . The Commission is currently investigating alleged anti-competitive conduct in the cement, cement products and other materials used in the production of cement and of cement-based products industries ... in the European Union / European Economic Area (EU/EEA).

2.... The alleged infringements relate to restrictions on trade in the European Economic Area (EEA), in particular restrictions on imports into the EEA from countries outside of the EEA, market-sharing and price-coordination practices as well as other anti-competitive practices relating thereto in the cement and related products markets. If their existence were to be confirmed, those acts could constitute an infringement of Article 101 TFEU and/or Article 53 of the EEA Agreement. ${ }^{28}$

The CJEU found that the statements of reasons were inadequate. ${ }^{29}$

It proceeded to note that it is true that the issue whether a statement of reasons meets the requirements of Article 296 TFEU must be evaluated by also taking into account the context in which the relevant decision was taken, and that in this case, the context included decisions to initiate proceedings. Nevertheless, even the statements of reasons for those decisions could not be seen as offsetting the faults of the statements of reasons in the information request decisions. ${ }^{30}$ The decisions to initiate proceedings contained vague expressions of possible infringement. For example, in the decision addressed to HeidelbergCement, it was referred to 'restrictions of trade flows in the European Economic Area (EEA) including restrictions on imports into the EEA from countries outside the EEA, market allocations, price coordination and related anti-competitive practices'.$^{31}$ The CJEU underlined that, in the decisions to initiate proceedings, the products which the investigation concerned were also described in general terms, referring to cement markets and related product markets but mentioning

28 See Commission Decision C (2011) 2361 final of 30 March 2011 relating to a proceeding under Article 18(3) of Council Regulation (EC) No. 1/2003, Case COMP/39520 - Cement and related products; Case C-247/14 P HeidelbergCement v. Commission EU:C:2016:149, para. 29.

29 See Cases C-247/14 P HeidelbergCement v. Commission EU:C:2016:149, para. 31; C-248/14 P Schwenk Zement v. Commission EU:C:2016:150, para. 35; C-267/14 P Buzzi Unicemv. Commission EU:C:2016:151, para. 32; C-268/14 P Italmobiliare v. Commission EU:C:2016:152, para. 33.

30 See, e.g., Case C-247/14 P HeidelbergCement v. Commission EU:C:2016:149, paras. 32-33; Case C-248/14 P Schwenk Zement v. Commission EU:C:2016:150, paras. 36-38.

31 See Case C-247/14 P HeidelbergCement v. Commission EU:C:2016:149, para. 34. See also Commission Press Release IP/10/1696 'Antitrust: Commission opens antitrust proceedings against a number of cement manufacturers', Brussels, 10 December 2010. 
more specific products only by way of example. Furthermore, as regards the geographical scope of the alleged infringement, the decisions contained nonexhaustive lists of several Member States. ${ }^{32}$

The CJEU moved on to note that it is true that a request for information is an investigative measure generally used at the investigation stage, before a formal statement of objections. ${ }^{33}$ Regarding inspection decisions the CJEU has held that even though the Commission is under an obligation to indicate what is sought and to what matters the inspection relates, the fact that inspections are carried out at the beginning of an investigation signifies that the Commission need not, for instance, precisely define the relevant market or explain the exact legal nature of presumed infringements. ${ }^{34}$

In the Cement case, the requests for information were issued more than two years after the first inspections, there had been earlier information requests, and at the time of adopting the information request decisions the Commission had information which would have allowed a more precise description of suspicions of infringement. The CJEU concluded that excessively vague - and partially ambiguous - statements of reasons could not fulfil the requirements relating to the obligation to state reasons in such a situation. ${ }^{35}$

Thus, the GC was considered to have erred in law when it found that the information request decisions at issue contained adequate statements of reasons. The heads of complaint relating to this issue were upheld for all Appellants, while other heads of complaint, including the GC's alleged failures to state sufficient reasons, were not examined. The CJEU set aside the relevant GC judgments and annulled the corresponding Commission information request decisions. $^{36}$

32 See e.g., Case C-247/14 P HeidelbergCement v. Commission EU:C:2016:149, paras. 35-36. See also, e.g., Case C-248/14 P Schwenk Zement v. Commission EU:C:2016:150, paras. 36-40.

33 See e.g., Case C-247/14 P HeidelbergCement v. Commission EU:C:2016:149, para 37. See also Case 374/87 Orkem EU:C:1989:387, paras. 20-24.

34 See Case C-37/13 P Nexans and Nexans v. Commission EU:C:2014:2030, paras. 35-37. See also, e.g., Case C-247/14 P HeidelbergCement v. Commission EU:C:2016:149, para. 38.

35 See Cases C-247/14 P HeidelbergCement v. Commission EU:C:2016:149, para. 39; C-248/14 P Schwenk Zement v. Commission EU:C:2016:150, para. 43; C-267/14 P Buzzi Unicem v. Commission EU:C:2016:151, para. 40; C-268/14 P Italmobiliare v. Commission EU:C:2016:152, para. 41.

36 See Cases C-247/14 P HeidelbergCement v. Commission EU: C: 2016:149, paras. 39-47; C-248/14 P Schwenk Zement v. Commission EU:C:2016:150, paras. 44-51; C-267/14 P Buzzi Unicem v. Commission EU:C:2016:151, paras. 41-48; C-268/14 P Italmobiliarev. Commission EU:C:2016:152, paras. $42-49$. 


\section{Discussion}

\subsection{Preliminary Remarks on the Significance of the Cement Case}

Commission competition investigations and the position, or procedural rights, of undertakings have been topical in recent CJEU cases, especially in the context of the early stages of investigations and fact-finding. ${ }^{37}$ The Cement Judgments elaborate on requirements for a statement of reasons in the context of Commission information request decisions under Article 18 of Regulation 1/2003. The clarifications may be relevant for other competition investigation fact-finding decisions as well.

Even though the Court focused only on the duty to state reasons (out of the several potential problems put forward by the Appellants), it is noteworthy that the AG Opinions in the Cement case highlight several interesting matters in terms of the relevant type of Commission decision and judicial review. AG Wahl found several of the Appellants' pleas convincing, and, for instance, in the Opinion regarding the action by HeidelbergCement, concluded that five out of seven grounds of appeal should be upheld. ${ }^{3}$

\subsection{Thorough AG Opinions}

The comprehensive AG Opinions may be interesting for undertakings assessing whether to question a fact-finding related Commission decision or its review by the GC.

For instance, and importantly, the AG highlighted that the GC seemed to have evaluated the issue of 'necessary information' erroneously, applying an incorrect test of necessity. For example HeidelbergCement argued in its appeal that the GC had applied an erroneous interpretation of necessity of information under Article 18 of Regulation 1/2003. ${ }^{39}$ AG Wahl underlined that 'A decision

See, in particular, Cases C-37/13 P Nexans and Nexans v. Commission EU:C:2014:2030; C-583/13

P Deutsche Bahn and Others v. Commission EU:C:2015:404.

38 See Opinion by AG Wahl in Case C-247/14 P HeidelbergCement v. Commission EU:C:2015:694, passim and para. 170. The five grounds that should be upheld, according to AG Wahl, were the GC's error of law when finding that the statement of reasons of the Commission decision was adequate, the GC's erroneous interpretation of necessary information, the CG's error of law when finding that the Commission was entitled to request information in a specific format, the GC's inadequate reasoning as regards vagueness of certain questions in the contested decision, and the GC's erroneous interpretation of the right not to incriminate oneself.

39 See Opinion by AG Wahl in Case C-247/14 P HeidelbergCement v. Commission EU:C:2015:694, para. 68 . 
requesting information which is not necessary within the meaning of Article 18 (3) of Regulation No 1/2003 is unlawful (in whole or in part) and, as such, ought to be annulled by the EU Courts. ${ }^{40}$

Indeed, the requirement that information requested must be necessary for investigations may be understood as limiting the scope of information the Commission may ask to be provided. Even though the Commission itself, as a starting point, defines what information is necessary for its investigations, it does not enjoy unlimited discretion in this matter..$^{41}$ According to the case law of the EU Courts, the necessity for information should be evaluated in relation to the purpose stated in the request, a central issue being whether the infringements the Commission aims to investigate are defined sufficiently clearly. ${ }^{42}$ Information requests which are not supported by a description of the purpose of the request may be legitimately questioned by undertakings as not complying with Article 18 of Regulation 1/2003.

In the Cement case, AG Wahl noted that the GC seemed to erroneously accept that any connection between information requested and a presumed infringement is enough to fulfil the requirement concerning necessary information. Even though the meaning of necessity is not in this context literal, in the sense of conditio sine qua non, the test now applied by the GC was, according to Wahl, too permissive. ${ }^{43}$ Wahl highlighted that an essential question should be whether information could reasonably be expected to be helpful to the Commission, and criticised the fact that the relevance of that aspect had been dismissed by the GC. ${ }^{44}$ The latter had stated, truly quite surprisingly when observed from the perspective of the wording of Regulation $1 / 2003$, that a possible lack of usefulness of the information sought would in any event not affect the lawfulness of the contested decision. ${ }^{45}$

Wahl also discussed the issue of information already previously requested and submitted, and information in the public domain, with a view to the concept of necessary information, noting that the necessity criterion might not be ful-

$40 \quad$ Ibid., para. 86.

41 See Case 155/79 AM \& S Europe Limited v. Commission EU:C:1982:157, para. 17. See also, e.g., Opinion by AG Wahl in Case C-247/14 P HeidelbergCement v. Commission EU:C:2015:694, paras. $70-81$.

42 See, e.g., notes 22-24 supra.

43 See Opinion by AG Wahl in Case C-247/14 P HeidelbergCement v. Commission EU:C:2015:694, paras. 71-72, 83-85.

44 See ibid., para. 85. See also Joined Cases T-458/o9 and T-171/10 Slovak Telekom v. Commission EU:T:2012:145, paras. 40-60.

45 See Case T-302/11 HeidelbergCement v. Commission EU:T:2014:128, paras. 54-58. 
filled when (new) requests for such information are made. ${ }^{46}$ Evidently, even the proportionality of such requests is questionable.

\subsection{Contributions and Clarifications in the Judgments}

\subsubsection{Comparability of Inspection Decisions and Information Request Decisions from the Perspective of Judicial Review}

Before looking into more substance-centred contributions visible in the Cement Judgments, it should be noted that the judgments also reveal matters relating to comparability of inspection and information request decisions and cases on reviewing them. As a starting point, the legal requirements for the Commission's information request decisions and for decisions ordering inspections (Art. 20 of Regulation 1/2003) are of a similar nature. This is discussed in the Cement case by AG Wahl, who, among other things, notes the similar wording of the relevant provisions. ${ }^{47}$ Additionally, the judgments illustrate the close relationships of information request and inspection decisions from the point of view of judicial review, as the CJEU discusses the obligation to state specific reasons also citing inspection decision review cases. ${ }^{48}$ In the case of both inspection and information request decisions, 'a light duty to state reasons' may be said to apply. ${ }^{49}$

The Cement Judgments nevertheless illustrate that evaluating fact-finding may differ in different situations. Even though the CJEU has held that the requirement to state the 'purpose of the request' includes the obligation to indicate the subject of the investigation and thus the alleged infringement, ${ }^{\circ}$ and that the Commission must indicate as precisely as possible what is being sought and the matters the investigation relates to, it has also, concerning review of Commission inspection decisions, communicated that it is not essential to precisely define the relevant markets, describe the exact legal nature of suspected infringements or to indicate the period during which alleged infringements were arguably committed..$^{1}$

\footnotetext{
46 See Opinion by AG Wahl in Case C-247/14 P HeidelbergCement AG v. Commission EU:C:2015:694, paras. 87-94.

Ibid., paras. 32-33.

48 See, e.g., Case C-247/14 P HeidelbergCement AG v. Commission EU:C:2016:149, para. 19.

49 See Prek/Lefèvre, 'Competition Litigation' 2016 (n. 5), 65-90, 83-86. See also Simonati, 'The Principles of Administrative Procedure' 2011 (n. 2), 45-82, 54, 77.

50 See Case C-36/92 P SEP NV v. Commission EU:C:1994:205, para. 21; Opinion by AG Jacobs in Case C-36/92 P SEP NVv. Commission EU:C:1993:928, paras. 22-34. See also e.g., Case C-247/14 P HeidelbergCement v. Commission EU:C:2016:149, para. 20.

51 See Case C-37/13 P Nexans and Nexans v. Commission EU:C:2014:2030, paras. 35-37.
} 
Now the CJEU has underlined that these findings had related to the fact that inspections take place at the beginning of an investigation, when no precise information is available to the Commission..$^{2}$ In the Cement case, 'an excessively succinct, vague and generic - and in some respects, ambiguous' statement of reasons in the decisions issued more than two years after the first inspections could not be considered in accordance with the obligation to state reasons under Article 18(3). The Commission had information which would have allowed it to describe its suspicions of infringements in more detail. ${ }^{53}$

The CJEU does not appear to try to draw a strong formal distinction between inspection decisions and information request decisions, but to highlight the difference between fact-finding at the very initial stages of an investigation and gathering information significantly later on in an investigation - and from undertakings that have been subjects of inspections and have submitted information.

4.3.2 The Fact that the Decision Type is normally used in the Early Stages of Investigation does not in itself justify a Vague Statement of Reasons

In particular, the Cement Judgments clarify the way in which the requirements for a statement of reasons in information request decisions interact with the context of a specific investigation.

The reasoning of the CJEU illustrates that even though EU law allows adaptation of the extent and level of detail of the statement of reasons to the situation in which the relevant decision is made, this does not mean that the general nature of information requests as instruments would directly justify a vague and concise statement of reasons. Information already obtained by the Commission and the time during which it has been able to investigate the relevant infringements are of relevance. If the Commission actually is able to present a more elaborate statement of reasons, an utterly vague and concise statement will not suffice. ${ }^{54}$

52 See, e.g., Case C-247/14 P HeidelbergCement v. Commission EU:C:2016:149, paras. 21, 24, 37-39. See also Case C-37/13 P Nexans and Nexans v. Commission EU:C:2014:2030, para. 37.

53 See, e.g., Case C-247/14 P HeidelbergCement v. Commission EU:C:2016:149, paras. 39-40.

54 See, e.g., ibid., paras. 38-39. See also Section 4.3.3 infra. 
4.3.3 Suspected Infringements must be indicated in a Manner which is not Excessively Vague - Issues in Judicial Review?

The Cement case illustrates the inherent difficulties relating to deciding standards for describing the purpose of a fact-finding measure, investigation and suspected competition infringements. The Cement Judgments form an addition to case law touching upon these themes.

In the information request decisions of the Cement case the inadequate indications of the purpose of requests and suspected infringements were remarkably vague. As AG Wahl aptly remarked, references to suspected infringements were all-encompassing and actually appeared to cover the 'vast majority of the types of agreement prohibited by Article 101 TFEU'.55 Additionally, the geographical scope and products affected were described in a partly ambiguous and non-exhaustive manner. ${ }^{56}$

In the inspection decision case Nexans where the statement of reasons including a description of suspected infringements had been drafted at an early stage of investigation and found to be acceptable regarding the aspect examined, the geographical scope of suspected infringement, by the CJEU, the descriptions were slightly more precise, but not entirely different from those in the Cement case. ${ }^{57}$ In an earlier stage of Nexans, the GC found that the scope of the investigation and search should have been expressly limited to products as to which there were actual suspicions of infringements. ${ }^{58}$ From the perspective of undertakings, the Cement Judgments constitute a welcome further development of case law by clearly requiring more precision as regards the focus of the investigation and alleged infringements, and emphasising the condition of the actual necessity for information.

These requirements might limit the comprehensiveness of the scope of information requested and even potentially encourage the Commission to abstain from frequent use of information request decisions within one investigation. From the standpoint of efficient competition law enforcement, gathering information should not, in any case, be constrained too much. Moreover, the issue of what is emphasised in judicial review is of importance here. The Commission may begin to focus on aspects strongly highlighted by the EU Courts but issue decisions which are otherwise problematic.

55 See, e.g., Opinion by AG Wahl in Case C-247/14 P HeidelbergCement v. Commission EU:C:2015:694, para. 37. See also more broadly paras. 36-39.

See, e.g., Case C-247/14 P HeidelbergCement v. Commission EU:C:2016:149, paras. 27-36.

See Case C-37/13 P Nexans and Nexans v. Commission EU:C:2014:2030, paras. 29-41 and 4.

58 See Case T-135/o9 Nexans and Nexans EU:T:2012:596. 
The Cement Judgments imply restraints on information request decisions especially later on in an investigation. Put simply: information request decisions with an extensive scope of information requested, accompanied by generic statements of reasons containing foggy, all-encompassing references to suspected infringements, are more acceptable at the very beginning of an investigation. ${ }^{59}$ One could also discern a possible problem here as regards incentives for the Commission.

A further intriguing issue is whether a precise description of suspected infringements that is nevertheless later considered unfounded or erroneous should be seen as complying with the provisions of Regulation 1/2003 and the legal principles relating to the position of undertakings. It may be easy also to write detailed descriptions on the purposes of investigations and suspected infringements in order to gather information, if it is irrelevant that at a later stage several or all of the suspicions are dropped. ${ }^{60}$ The Commission enjoys a broad discretion as regards its investigative efforts and is able to prioritise its work and decide on the investigation lines it follows. ${ }^{6}$ Additionally, at the fact-finding stage, details of an investigation are mainly secret. ${ }^{62}$

Nevertheless, the requirement to indicate the aim of the investigation and suspected infringements cannot be seen as a mere formal requirement which would allow requesting or searching for any information as long as the indication of the purpose has, at the time of gathering information, been written in a manner which suits a fact-finding exercise. The issue of necessity of information or search has an interface with the prohibition on arbitrary and disproportionate measures by public authorities. If not the concept of necessity in itself, this prohibition at least bans highly speculative information requests and searches under Articles 18 and 20 of Regulation 1/2003. The Commission must have reasonable grounds for suspecting a competition infringement and for adopting an information gathering decision (even though those grounds need not be communicated to undertakings in their entirety and are not necessarily examined by the EU Courts). ${ }^{6}$

59 See also Opinion by AG Wahl in Case C-247/14 P HeidelbergCement v. Commission

EU:C:2015:694, para. 50 .

6o As regards describing the scope of the investigation vaguely and thus broadening the scope of what might be considered necessary information, see also ibid., paras. 53-54.

61 See Arts. 7-8 and 10 of Regulation 1/2003. See further, e.g., L. Ortiz Blanco/K. Jörgens/ M. Tierno Centella, 'The Organization of European Commission Proceedings', in Ortiz Blanco, EU Competition Procedure 2013 (n. 5), 167-221, 199-200.

62 See also, e.g., T-135/o9 Nexans and Nexans EU:T:2012:596, para. 69. See further critical discussion by Prek/Lefevre, 'Competition Litigation' 2016 (n. 5), 65-90, 82-89.

63 See Opinion by AG Wahl in Case C-247/14 P HeidelbergCement v. Commission EU:C:2015:694, paras. 23-24 and 73-79. See further Case C-94/o0 Roquette Frères EU:C:2002:603, paras. 27, 55, 70, 99, and the GC in Case T-296/11 Cementos Portland Valderrivas v. Commission EU:T:2014:121, paras. 40-56. See also Case C-37/13 P Nexans and Nexans v. Commission EU:C:2014:2030, para. 34. See, however, as regards the threshold for investigating underlying 
Furthermore, the CJEU has underlined that the duty to indicate infringements investigated is relevant for the possibility of undertakings to evaluate their obligation to cooperate and to exercise their rights of defence. ${ }^{64}$

All this signifies that, in the context of decisions under Articles 18 and 2o, descriptions of suspected infringements should be relatively well-thought through and justified. However, evaluation difficulties will probably always arise from the fact that the same suspicions may seem justified at one stage and unjustified at another stage of an investigation - and from the fact that concepts such as 'justified suspicion' are themselves tricky as a yardstick.

It is evident that setting judicial standards for reviewing the Commission's ideas on possible competition infringements and information or search necessary for investigating them remains challenging. ${ }^{65}$

\subsection{The Significance and Implications of the Judgments in Practice}

One aspect of the de facto implications of the Cement Judgments is the approach of the Commission to the relevance of the judgments. Earlier, when the GC issued its judgments upholding the relevant Commission information request decisions, the Commission came forward with a statement welcoming the judgments:

'These judgments are important because they confirm the scope of the Commission's powers to investigate suspected antitrust infringements. In particular, the Court confirmed that it is for the Commission to decide what information it considers necessary to request from companies when investigating potential anticompetitive practices, as long as the Commission can reasonably expect that the information would help it to determine whether the alleged infringement took place. ${ }^{, 66}$

Notably, after the CJEU judgments, a spokesperson for the Commission reportedly commented that 'The implications of the judgments are likely to be

facts or for finding that the underlying facts do not justify presented suspicion, Joined Cases 97/87 to 99/87 Dow Chemical EU:C:1989:380, paras. 52-53, and the GC in Case T-135/09 Nexans and Nexans EU:T:2012:596, para. 72. As to discussion, see Prek/Lefevre, 'Competition Litigation' 2016 (n. 5), 65-90, 86-89.

64 See, e.g., note 19 supra.

65 See also Section 4.2 supra.

66 Commission Memo MEMO/14/192 'Antitrust: Commission welcomes General Court judgments in cement cartel case confirming its investigatory powers', Brussels, 14 March 2014. 
confined to the present case, as the ECJ pronounced itself only on the issue of reasoning. ${ }^{67}$

Commentators have disagreed with the reported Commission comment and considered the Cement Judgments important, potentially contributing to better clarity and specificity of Commission information gathering decisions, as well as conceivably limiting the scope of information requests. ${ }^{68}$

Indeed, it is perceivable that the judgments, and even the comprehensive AG Opinions, are of notable significance as regards the appropriateness of Commission information request decisions and, more broadly, any fact-finding decisions. One would expect the Cement Judgments to encourage the Commission to consider closely what information should be requested (or searched), with what kind of reasoning, and at what point information request decisions would optimally be adopted. A central question is whether the Commission is now actively trying to develop its decisions or whether the way to more elaborate fact-finding decisions is through learning from further strict judicial review. It is possible that the $\mathrm{GC}$ will now pay particular attention to appropriately reviewing relevant Commission measures.

67 See, e.g., F. Carloni/G. Da Costa, 'Judgments in the Cement Case: Requirement for Greater Clarity, Specificity, and Justification of Information Requests from the Commission', Journal of European Competition Law \& Practice, 10.1093/jeclap/lpwo32, advance access 29 April 2016; C. Riis-Madsen/C. Jacquot, 'The European Commission's Investigative Powers Curtailed by the EU Court', O'Melveny Publications (14 March 2016), www.omm.com/resources/alerts-andpublications/alerts/the-european-commissions-investigative-powers-curtailed-by-the-eu-court/ (accessed 11 June 2016).

68 See, e.g., Carloni/G. Da Costa, 'Judgments in the Cement Case' 2016 (n. 67); A. Lamadrid, 'The ECJ annuls the General Court's Judgments and the Commission's decisions in the cement case (on the limits of information requests)', Chillin' Competition (10 March 2016), chillingcompetition.com/2016/03/10/the-ecj-annuls-the-general-courts-judgments-and-the-commissionsdecisions-in-the-cement-case-on-the-limits-of-information-requests/ (accessed 11 June 2016). 
Copyright of Review of European Administrative Law is the property of Paris Legal Publishers and its content may not be copied or emailed to multiple sites or posted to a listserv without the copyright holder's express written permission. However, users may print, download, or email articles for individual use. 